\title{
PENINGKATAN PROSES DAN HASIL BELAJAR MUATAN IPA MELALUI PENERAPAN MODEL PROBLEM BASED LEARNING PADA TEMA 8 SUBTEMA 1
}

\author{
Ayu Siti Nur Hekmah ${ }^{1}$, Nyoto Harjono ${ }^{2}$, Gamaliel Septian Airlanda ${ }^{3}$ \\ 1,2,3 Jurusan Pendidikan Guru Sekolah Dasar, FKIP \\ Universitas Kristen Satya Wacana \\ Salatiga, Indonesia \\ email : ayusitinh@gmail.com ${ }^{1}$, har.john59@gmail.com² \\ gama.airlanda@staff.uksw.edu ${ }^{3}$
}

\begin{abstract}
Abstrak
Penelitian ini bertujuan meningkatkan proses dan hasil belajar muatan IPA siswa kelas 5 SDN Salatiga 10 melalui penerapan model Problem Based Learning.Jenis penelitian yang digunakan adalah penelitian tindakan kelas. Instrumen pengumpulan data menggunakan rubrik penilaian proses aktivitas guru dan siswa,serta tes. Analisis data dilakukan dengan membandingkan kondisi awal, hasil siklus I dan II. Hasil penelitian menunjukkan model PBL dapat: a) meningkatkan proses aktivitas guru,pada kondisi awal $46,66 \%$, meningkat menjadi $76,47 \%$ pada siklus I dan meningkat menjadi $88,57 \%$ pada siklus II. b) meningkatkan proses aktivitas siswa, padakondisi awal $39,16 \%$, meningkat menjadi $65,58 \%$ pada siklus I dan meningkat menjadi $85 \%$ pada siklus II. c) meningkatkan hasil belajar muatan IPA Tema 8 Subtema 1. Hasil belajar pada kondisi awal persentase pencapaian KKM sebesar 15\% (5 siswa), pada siklus I meningkat menjadi $79 \%$ (26 siswa) dan pada siklus II meningkat menjadi $90 \%$ (30 siswa) dari jumlah keseluruhan 33 siswa.
\end{abstract}

Kata kunci: Muatan IImu Pengetahuan Alam, hasil belajar, model pembelajaran problem based learning (PBL).

\begin{abstract}
This study aims to improve the process and the results of learning science content of grade 5 SDN Salatiga 10 through the application of Problem Based Learning model. The type of research used is classroom action research. The data collection instrument uses the rubric of assessment process of teacher and student activity, and test. Data analysis was done by comparing initial condition, cycle result I and II. The results showed that PBL model can: a) improve teacher activity process, at initial condition $46,66 \%$, increase to $76,47 \%$ in cycle I and increase become $88,57 \%$ in cycle II. b) improving student activity process, at initial condition of $39,16 \%$, increasing to $65,58 \%$ in cycle I and increasing to $85 \%$ in cycle II. c) Improving the results of the teaching of content of IPA Theme 8 Subtema 1. The learning outcomes at the initial condition of the percentage of achievement of $15 \%$ (5 students), in the first cycle increased to $79 \%$ (26 students) and in cycle II increased to $90 \%$ (30 students) of 33 students.
\end{abstract}

Keywords: Content of Natural Science, learning outcomes, learning-based problem-based learning (PBL) model. 


\section{Pendahuluan}

Peraturan Pemerintah Nomor 32 Tahun 2013 mengenai Standar Pendidikan Nasional terkait standar proses menyatakan bahwa proses pembelajaran pada satuan pendidikan diselenggarakan secara inspiratif, interaktif, menyenangkan, menantang, dapat memotivasi peserta didik supaya lebih aktif, serta memberikan kesempatan peserta didik untuk mengembangkan kreativitas, bakat, minatnya. Oleh karena itu dalam satuan pendidikan melakukan perencanaan, pelaksanaan dalam proses pembelajaran kemudian melakukan penilaian proses pembelajaran. Hal tersebut bertujuan meningkatkan keefektifan ketercapaian kompetensi lulusanyang diharapkan. Oleh sebab itu siswa dituntut supaya lebih aktif serta kreatif dan juga mandiri dalam proses kegiatan pembelajaran melalui bimbingan guru.

Dalam kurikulum 2013 yang menekankan keseimbangan antara soft skills dan hard skills yang meliputi aspek kompetensi sikap (afektif), keterampilan (psikomotorik), dan pengetahuan (kognitif). Dari ketiga aspek penilaian tersebut tentunya mengharapkan siswa agar lebih kreatif, inovatif, aktif serta mengedepankan proses dalam belajar. Pembelajaran yang digunakan dalam kurikulum 2013 adalah pembelajaran tematik terpadu yang mengedepankan siswa untuk aktif dalam pembelajaran dan secara individu mencari berbagai sumber pengetahuan, kemudian mengembangkan pengetahuannya secara mandiri. Proses pembelajaran yang menekankan pada pemberian pengalaman langsung dan mencari pengetahuannya secara mandiri dapat meningkatkan pemahaman siswa serta meningkatkan proses dan hasil belajar siswa. Hasil belajar merupakan akhir dari berhasilnya siswa dalam belajar dari tujuan belajar yang dilakukan Kristin (2016: 92). Hasil belajar dapat dikatakan sebagai tolok ukur ketercapaian tujuan dari kegiatan belajar.

Observasi yang dilakukan di kelas 5 SDN Salatiga 10, dalam proses pembelajaran guru saat mengajar muatan IPA sudah menggunakan media pembelajaran yang sesuai dengan materi, karena sekolah dasar tersebut juga sudah banyak memiliki media pembelajaran untuk menunjang dalam proses belajar. Meskipun guru sudah menggunakan media pembelajaran namun masih terdapat siswa yang mendapatkan nilai dibawah kriteria ketuntasan minimal. Hal ini terlihat dari hasil ulangan IPA yang telah peneliti dapatkan dari guru kelas 5 SDN Salatiga 10, yaitu sebanyak 22 siswa atau 67\% dari 33 jumlah siswa yang mendapatkan nilai dibawah KKM 75. Sedangkan siswa yang mendapatkan nilai diatas kriteria ketuntasan minimal, yaitu 11 siswa atau 33\% dari 33 jumlah siswa. Sebagai sekolah dasar yang sudah mempunyai banyak prestasi dan memiliki akreditasi baik, nilai yang dipeoleh siswa kelas 5 pada muatan IPA tersebut dirasa kurang memuaskan menurut peneliti, sehingga masih perlu diadakan perbaikan dalam kegiatan pembelajaran. Perbaikan terseut berguna supaya dalam proses pembelajaran siswa memiliki pengalaman langsung dalam belajar, supaya siswa lebih aktif, kreatif dan mengembangkan pengetahuan yang telah mereka miliki. Siswa tidak hanya mendengarkan penjelasan dari guru melainkan siswa dituntut agar aktif dalam mencari sumber belajar dan pengetahuan.

Perbaikan yang dilakukan dengan melakukan penelitian untuk mengkaji peningkatan hasil belajar muatan IPA melalui penerapan model pembelajaran problem based learning dalam pembelajaran pada Tema 8, Subtema 1 Manusia dan Lingkungan, di kelas 5 SDN Salatiga 10. Model pembelajaran tersebut dipilih guna meningkatkan proses dan hasil belajar muatan IPA siswa kelas 5 SDN Salatiga 10. Pembelajaran dengan model PBL merupakanmodel pembelajaran yang berkaitan langsung dengan kehidupan nyata siswa, oleh sebab itu diharapkan siswa mampu memahami suatu masalah di dalam kehidupan sehari-hari, Suyatno (2009: 58). Model pembelajaran problem based learning merupakan pembelajaran yang menyenangkan bagi siswa serta memberika pengalaman bagi siswa dalam menemukan penyelesaian suatu masalah dan meningkatkan keterampilan berpikir kritis.Penlitian ini diharapkan dapat meningkatkan proses pembelajaran IPA dan meningkatkan hasil belajar IPA siswa. 


\section{Metode}

Penelitian ini dilaksanakan pada bulan Februari-Mei 2018. Penelitian ini dilaksanakan di SDN Salatiga 10, Jalan Margosari Nomor 03 Salatiga, Kecamatan Sidorejo, Kota Salatiga, Jawa Tengah. SDN Salatiga 10 memiliki 6 ruang kelas, 1 ruang guru yang digabung dengan ruang tamu, 1 ruang kepala sekolah. Penelitian ini dilakukan secara bertahap yaitu, melalui tahap persiapan penelitian, tahap pelaksanaan penelitian, tahap penyusunan laporan penelitian. Tahap persiapan dilakukan dengan penyusunan judul, penyusunan proposal, penyusunan RPP, penyusunan instrumen penelitian, permohonan surat izin untuk observasi. Tahap pelaksanaan penelitian meliputi kegiatan yang dilakukan di sekolah untuk pengambilan data. Tahap penyusunan laporan penelitian mencangkup pengolahan data dan penyusunan laporan untuk persiapan ujian.

Subjek Penelitian ini adalah siswa kelas 5 SDN Salatiga 10 tahun pelajaran 2017/2018. Jumlah siswa kelas 5 SDN Salatiga 10 yang berjumlah 33 orang siswa. Hasil pembelajaran pada muatan IPA yang diperoleh masih rendah dan siswa kurang begitu aktif dalam mengikuti pembelajaran di kelas. Karena hal tersebut maka perlu diambil tindakan untuk meningkatkan hasil belajar.

Dalam penelitian tindakan kelas yang dilakukan ini, terdapat dua variabel yang diteliti yaitu variabel bebas dan variabel terikat. Variabel bebas dilakukan yang fungsinya untuk menimbulkan variabel lain. Yang termasuk dalam variabel bebas meliputi kegiatan guru saat mengajar, keadaan siswa ketika berada di dalam kelas, dan penggunaan metode pembelajaran. Dalam penelitian yang telah dilakukan yang termasuk kedalam variabel bebas adalah penerapan model pembelajaran problem based learning $(\mathrm{X})$. Model problem based learning akan diterapkan pada kelas 5 SDN Salatiga 10 tahun pelajaran 2017/2018 dalam pembelajarn IPA. Variabel bebas akibat dari pengaruh variabel bebas. Variabel ini berkaitan dengan motivasi belajar dan hasil belajar. Dalam penelitian ini variabel terikat adalah peningkatan proses belajar $\left(y^{1}\right)$ dan hasil belajar muatan IPA siswa kelas 5 SDN Salatiga 10 (Y) setelah dilakukan pembelajaran dengan menggunakan model pembelajaran problem based learning adalah $\left(\mathrm{y}^{2}\right)$.

Penelitian tindakan kelas ini mengacu pada desain dari Kemmis dan Taggart. Desain penelitian ini memiliki tahap yang terdiri dari: 1) Perencanaan (planing) merupakan susunan rancangan penelitian yang sudah disesuaikan dengan objek dan masalah yang sudah diperbaiki ataupun sudah ditingkatkan, 2) Tindakan (action) merupakan implementasi dari seluruh rancangan yang telah dibuat dan disusun dengan baik agar tujuan dapat tercapai, dan pengamatan (observing) adalah proses mengamati dampak dari tindakan yang telah dilakukan, apakah mengalami perubahan atau tidak, 3) Refleksi (reflecting) merupakan tahap mengulas kembali apa yang sudah dilakukan untuk melihat adakah kekurangan atau ketidak adanya hasil dari tindakan tersebut dan kemudian menyusun perencanaan kembali pada siklus berikutnya (Pujiono,2008:3).

Tenik pengumpulan data yang digunakan dalam penelitian ini adalah teknik tes dan non tes/observasi. Untuk mengukur hasil belajar digunakan teknik tes, yang nantinya akan dibandingkan antara hasil belajar pra-siklus dengan hasil siklus I dan siklus II untuk mengetahui apakah terjadi peningkatan nilai yang dicapai oleh siswa sebagai indikator peningkatan hasil belajar. Sedangkan teknik non tes/observasi berupa pengamatan aktivitas guru dalam penerapan langkah-langkah model pembelajaran problem based learning yang berupa daftar pernyataan aktivitas guru. Sedangkan untuk pengamatan aktivitas siswa digunakan untuk mengamati segala aktivitas siswa dalam proses pembelajaran.

Dalam mengukurhasil belajar menggunakan butir soal yang sebelumnya telah diuji validitasnya. Validitas yang digunakan untuk mengukur tingkat valid data. Dalam mengukur tingkat validitas dapat digunakan untuk mengkorelasikan setiap skor pada butir instrumen dengan total skor yang dapat dilihat melalui analisis SPSS 16.0 for Windows.Kriteria uji validitas instrumen adalah $\leq 0.7$ dikatakan tidak ada validitas, $0.7<a \leq 0.8$ dikatakan dapat diterima, $0.8<a \leq 0.9$ dikatakan reliabilitas bagus, dan $\geq 0.9$ dikatakan reliabilitas 
memuaskan. Setelah uji validitas kemudian dilakukan uji reliabilitas. Reliabilitas adalah derajat konsistensi suatu instrumen. Instrumen yang reliabel dapat digunakan beberapa kali untuk mengukur objek yang sama akan menghasilkan data yang sama. Untuk mengetahui reliabilitas instrumen jawaban siswa terhadap pertanyaan dalam item instrumen menggunakan metode Alpha (Cronbach's).besarnya koefisien alpha merupaka tolok ukur dari tingkat reliabilitasnya. Uji reliabilitas ini dilakukan dengan menggunakan program SPSS 16.0 for Windows.Kriteria uji reliabilitas instrumen adalah $r<0.20$ dalam kategori sangat rendah, $0.21 \leq r<0.40$ dalam kategori rendah, $0.41 \leq r<0.60$ dalam kategori cukup, $0.61 \leq r$ $<0.80$ dalam kategori tinggi dan $0.81 \leq r<1.00$ dalam kategori sangat tinggi.

\section{Hasil dan Pembahasan}

\section{Kondisi Prasiklus}

Pembelajaran yang dilakukan di kelas 5 SDN Salatiga 10 belum efektif dikarenakan pembelajaran guru dalam mengajar masih konvensional. Berdasarkan observasi yang dilakukan di kelas 5 SDN Salatiga 10 sebelum penelitian dilaksanakan pada semester II tahun pelajaran 2017/2018 menunjukkan hasil belajar dan proses pembelajaran masih rendah. Data hasil observasiaktivitas guru dan siswa dapat dilihat pada diagram berikut ini:

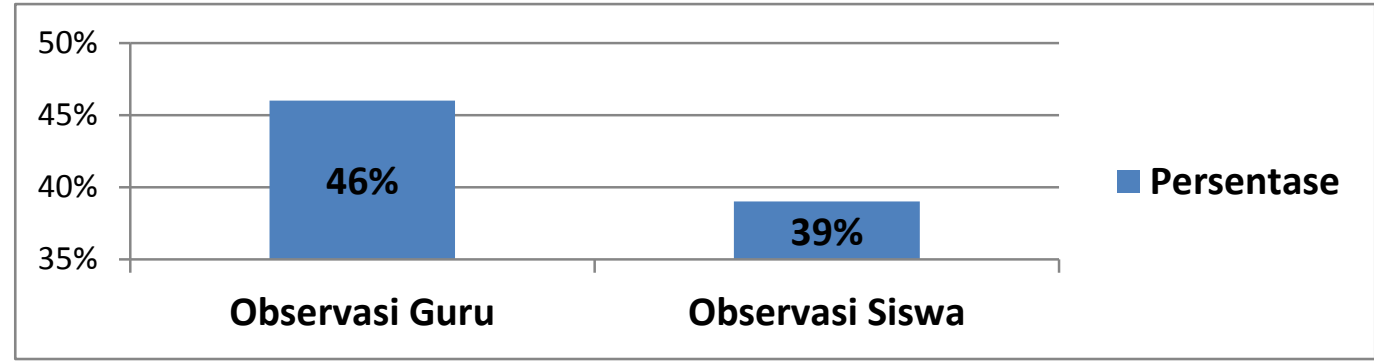

Diagram 1. Persentase Hasil Observasi Aktivitas Guru dan Siswa Kondisi Awal

Hasil observasi guru dan hasil observasi siswa yang telah dilakukan pada kondisi awal memperoleh hasil yang dapat dikatakan cukup rendah. Hasil observasi aktivitas guru, memperoleh skor 49 dari jumlah skor keseluruhan 105 dengan persentase sebesar $46 \%$. Hasil observasi aktivitas siswa, memperoleh skor 47 dari jumlah skor keseluruhan 120 dengan persentase sebesar 39\%.Data hasil belajar muatan IPA dapat dilihat pad atabel berikut ini:

Tabel 1. Hasil Belajar Muatan IPA Kelas 5 SDN Salatiga 10 Pada Kondisi Awal

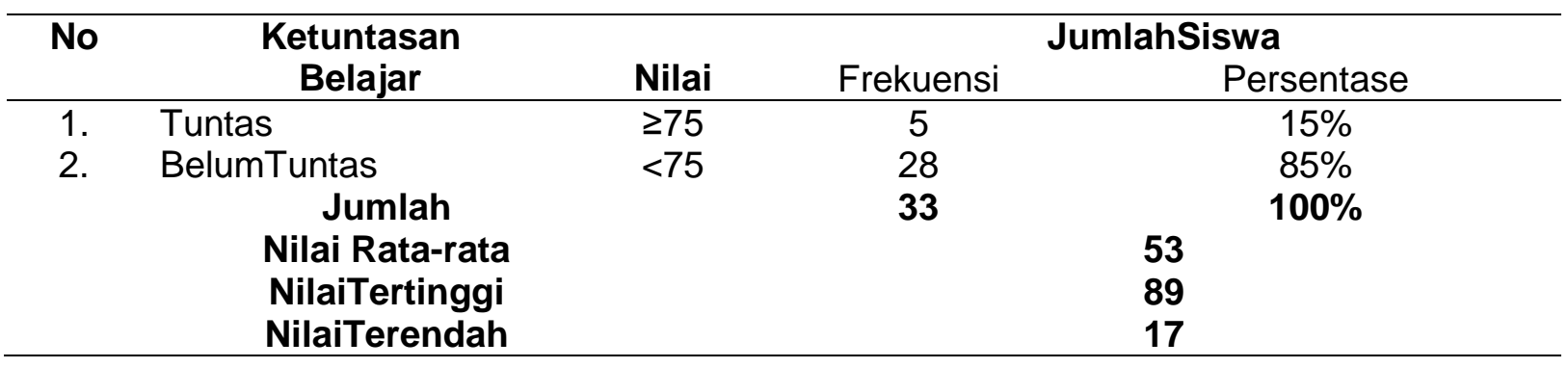

Dari data di atas dapat dilihat bahwa hasil belajar pada kondisi awal dapat diketahui terdapat 28 siswa atau $85 \%$ dari total keseluruhan siswa yang memiliki nilai kurang dari Kriteria Ketuntasan Minimal $(K K M \geq 75)$ dan 5 siswa atau 15\% dari total keseluruhan sudah mencapai Kriteria Ketuntasan Minimal (KKM). Nilai rata-rata pada kondisi awal 53, dengan nilai maksimal 89 dan nilai minimal 17 . 


\section{Siklus I}

Setelah pelaksanaan siklus I terdapat peningkatan hasil observasi aktivitas guru dan siswa pada tiap pertemuannya serta terjadi peningkatan pada hasil belajar muatan IPA kelas5 SDN Salatiga 10. Hasil observasi aktivitas guru dan siswa pada siklus I dapat dilihat pada diagram berikut ini:

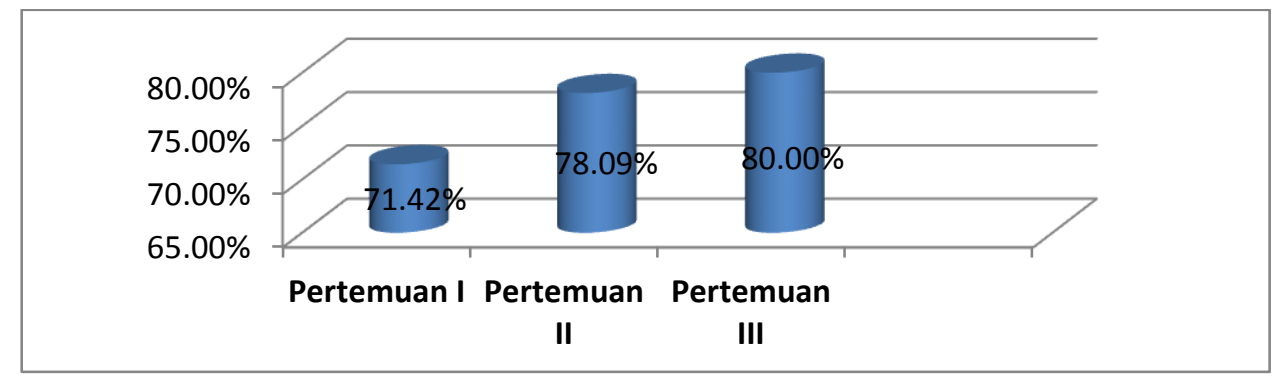

Diagram 2. Peningkatan Persentase Hasil Observasi Aktivitas Guru Siklus I Pertemuan I, II dan III

Hasil observasi pada siklus I dengan indikator penilaian aktivitas guru sebanyak 21 item dengan total skor keseluruhan 105, hasil persentase aktivitas guru pertemuan pertama sebesar $71,42 \%$ dengan perolehan skor 75 dari total skor keseluruhan 105, pertemuan kedua mengalami peningkatan menjadi $78,09 \%$ dengan perolehan skor 82 dari total skor keseluruhan 105 dan pada pertemuan ketiga juga mengalami peningkatan menjadi 80,00\% dengan perolehan skor 84 dari total skor keseluruhan 105. Peningkatan juga terjadi pada observasi aktivitas siswa, data hasil observasi aktivitas siswa dapat dilihat pada diagram berikut ini:

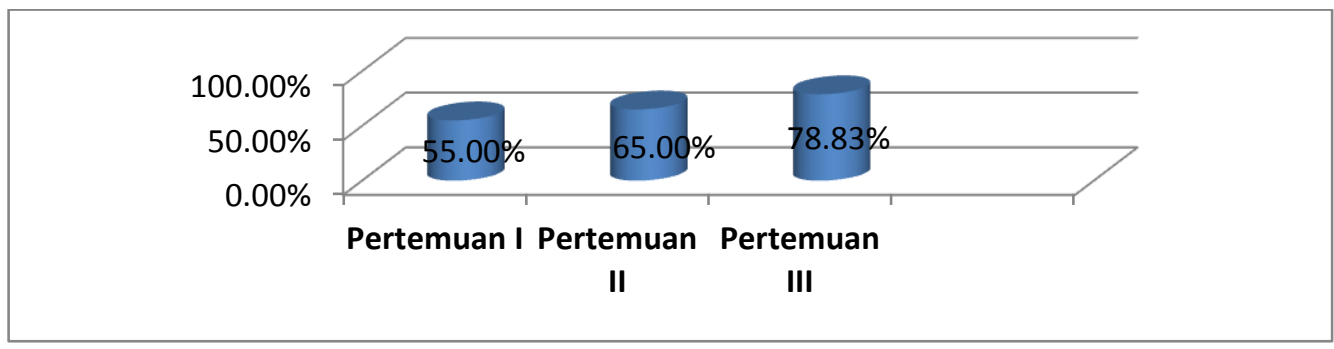

Diagram 3. Peningkatan Persentase Hasil Observasi Aktivitas Siswa Siklus I Pertemuan I, II dan III

Hasil observasi pada siklus I dengan indikator penilaian aktivitas siswa sebanyak 24 item dengan total skor keseluruhan 120 , hasil persentase aktivitas siswa pertemuan pertama sebesar 55,00\% dengan perolehan skor 66 dari total skor keseluruhan 120, pertemuan kedua mengalami peningkatan menjadi $65,00 \%$ dengan perolehan skor 78 dari total skor keseluruhan 120 dan pada pertemuan ketiga juga mengalami peningkatan menjadi $70,83 \%$ dengan perolehan skor 85 dari total skor keseluruhan 120. Selain aktivitas guru dan siswa mengalami peningkatan, hasil belajar muatan IPA juga mengalami peningkatan. Terdapat lebih banyak siswa yang telah tuntas pada pembelajaran muatan IPA dibandingkan dari sebelum dilaksanakannya siklus I. Ketuntasan belajar siklus I dapat dilihat pada tabel berikut ini: 
Tabel 2. Ketuntasan Belajar Siklus I

\begin{tabular}{|c|c|c|c|c|}
\hline \multirow[t]{2}{*}{ No } & \multirow{2}{*}{$\begin{array}{c}\text { Ketuntasan } \\
\text { Belajar }\end{array}$} & \multirow[t]{2}{*}{ Nilai } & \multicolumn{2}{|c|}{ JumlahSiswa } \\
\hline & & & Frekuensi & Persentase \\
\hline 1 & Tuntas & $\geq 75$ & 26 & $79 \%$ \\
\hline \multirow[t]{5}{*}{2} & BelumTuntas & $<75$ & 7 & $21 \%$ \\
\hline & Jumlah & & 33 & $100 \%$ \\
\hline & Rata-rata Nilai & & \multicolumn{2}{|c|}{79,2} \\
\hline & NilaiTertinggi & & \multicolumn{2}{|c|}{92} \\
\hline & NilaiTerendah & & \multicolumn{2}{|c|}{50} \\
\hline
\end{tabular}

Pada tabel di atas hasil belajar pada siklus I diketahui dari 33 siswa yang tuntas mencapai KKM 26 siswa dengan persentase 79\%, sedangkan siswa yang belum tuntas terdapat 7 siswa dengan persentase $21 \%$ dari total keseluruhan siswa. Rata-rata nilai kelas yang diperoleh pada siklus I adalah 79,2 dengan nilai maksimal 92dan nilai minimal 50.

\section{Siklus II}

Pada pelaksanaan siklus II hasil observasi aktivitas guru dan siswa serta hasil belajar muatan IPA kelas 5 SDN Salatiga 10, kembali mengalami peningkatan. Hasil observasi aktivitas guru dan siswa pada siklus II dapat dilihat pada diagram berikut ini:

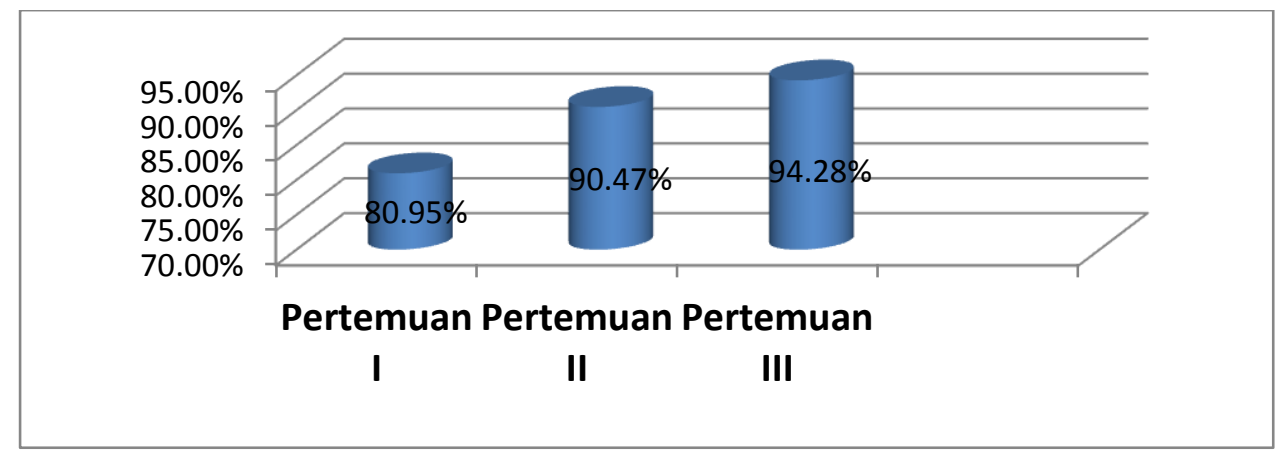

Diagram 4. Peningkatan Persentase Hasil Observasi Aktivitas Guru Siklus II Pertemuan I, II dan III

Hasil observasi pada siklus I dengan indikator penilaian aktivitas guru sebanyak 21 item total skor keseluruhan 105, hasil persentase aktivitas guru pertemuan pertama sebesar $80,95 \%$ perolehan skor 85 dari total skor keseluruhan 105, pertemuan kedua mengalami peningkatan menjadi 90,47\% perolehan skor 95 dari total skor keseluruhan 105 dan pada pertemuan ketiga juga mengalami peningkatan menjadi 94,28\% perolehan skor 99 dari total skor keseluruhan 105. Pada siklus II peningkatan juga terjadi pada observasi aktivitas siswa, data hasil observasi aktivitas siswa pad asiklus II dapat dilihat pada diagram berikut ini:

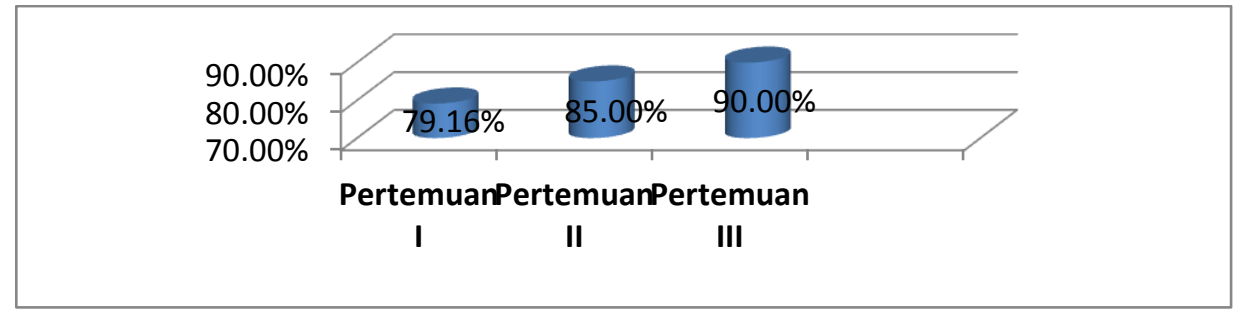

Diagram 5. Peningkatan Persentase Hasil Observasi Aktivitas Siswa Siklus II Pertemuan I, II dan III 
Hasil observasi pada siklus II dengan indikator penilaian aktivitas siswa sebanyak 24 item dengan total skor keseluruhan 120, hasil persentase aktivitas siswa pertemuan pertama sebesar $79,16 \%$ dengan perolehan skor 95 dari total skor keseluruhan 120, pertemuan kedua mengalami peningkatan menjadi $85,00 \%$ dengan perolehan skor 102 dari total skor keseluruhan 120 dan pada pertemuan ketiga juga mengalami peningkatan menjadi $90,00 \%$ dengan perolehan skor 108 dari total skor keseluruhan 120. Selain aktivitas guru dan siswa mengalami peningkatan pada kegiatan siklus II, hasil belajar muatan IPA juga mengalami peningkatan. Ketuntasan belajar siklus II dapat dilihat pada tabel berikut ini:

Tabel 3. Ketuntasan Belajar Siklus II

\begin{tabular}{ccccc}
\hline No & Ketuntasan & Nilai & \multicolumn{2}{c}{ Jumlah Siswa } \\
& Belajar & & Frekuensi & Persentase \\
\hline 1 & Tuntas & $\geq 75$ & 30 & $90 \%$ \\
2 & Belum Tuntas & $<75$ & 3 & $10 \%$ \\
Jumlah & & 33 & $100 \%$ \\
& Rata-rata Nilai & & 85 & \\
Nilai Tertinggi & & & 100 & \\
& Nilai Terendah & & 58 & \\
& & & & \\
\end{tabular}

Dari data di atas hasil belajar pada siklus II diketahui dari 33 siswa yang memperoleh nilai diatas KKM meningkat dari 26 siswa dengan persentase $79 \%$ menjadi 30 siswa dengan persentase $90 \%$, sedangkan siswa yang belum tuntas terdapat 3 siswa dengan persentase $10 \%$ dari sebelumnya terdapat 7 siswa dengan persentase $21 \%$ siswa yang belum tuntas. Rata-rata kelas juga mengalami peningkatan dari 79,2 menjadi 85 , dengan perolehan nilai maksimal yang diraih siswa adalah 100 dan nilai minimal 58.

Berdasarkan analisis ketuntasan hasil belajar serta hasil observasi aktivitas guru dan siswa siklus I dan siklus II maka dapat analisis komparatif ketuntasan hasil belajar dan hasil observasi dari kedua siklus. Analisis yang dilakukan dengan menyajikan data yang diperoleh dari hasil belajar dan hasil observasi pada kondisi awal, siklus I, dan siklus II dalam bentuk tabel. Data kemudian dibandingkan dengan indikator kinerja yang sudah ditetapkan. Perbandingan persentase observasi aktivitas guru pada kondisi awal, siklus I, dan siklus II dapat dilihat pada diagram berikut ini:

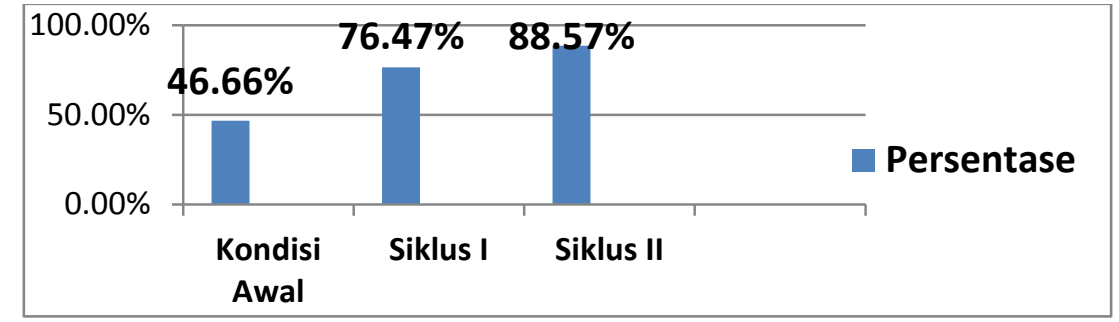

Diagram 6. Perbandingan Persentase Observasi Aktivitas Guru Pada Kondisi Awal, Siklus I, dan Siklus II

Dari diagram di atas dapat dilihat terjadi peningkatan persentase observasi aktivitas guru pada kondisi awal 46,66\% dengan rata-rata skor 49 dari jumlah skor keseluruhan 105 , meningkat menjadi 76,47\% dengan rata-rata skor 80,3 dari jumlah skor keseluruhan 105 pada siklus I, dan mengalami peningkatan kembali pada siklus II menjadi $88,57 \%$ dengan 
rata-rata skor 93 dari jumlah skor keseluruhan 105. Perbandingan persentase observasi aktivitas siswa pada kondisi awal, siklus I, dan siklus II dapat dilihat pada diagram 2 berikut ini:

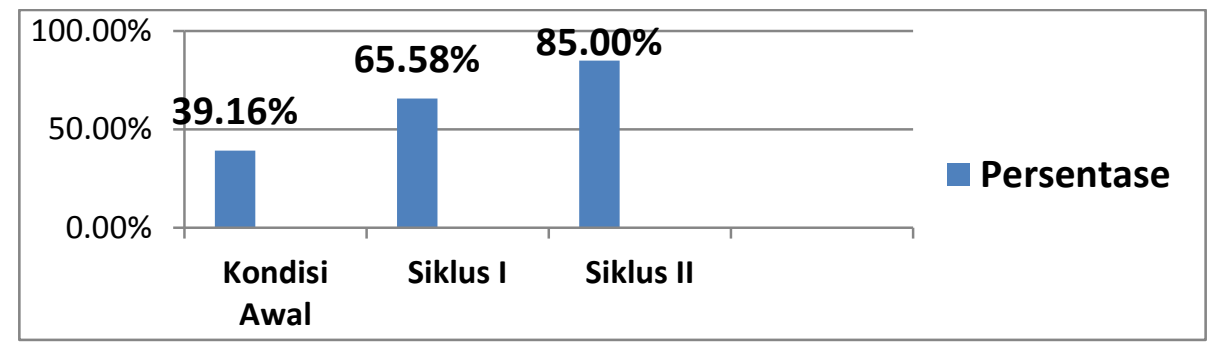

Diagram 7. Perbandingan Persentase Observasi Aktivitas Siswa Pada Kondisi Awal, Siklus I, dan Siklus II

Berdasarkan perbandingan persentase observasi aktivitas siswa pada kondisi awal $39,16 \%$ dengan rata-rata skor 47 dari jumlah skor keseluruhan 120, meningkat menjadi $65,58 \%$ pada siklus I dengan rata-rata skor 76 dari jumlah skor keseluruhan 120, dan pada siklus II mengalami peningkatan kembali menjadi $85.00 \%$ dengan rata-rata skor 102 dari jumlah skor keseluruhan 120. Dari hasil data yang telah diperoleh terlihat bahwa hasil observasi aktivitas guru dan siswa pada setiap siklusnya mengalami peningkatan. Peningkatan tersebut juga berpengaruh pada ketuntasan hasil belajar muatan IPA siswa kelas 5 SDN Salatiga 10. Perbandingan ketuntasan belajar pada kondisi awal, siklus I dan siklus II dapat dilihat pada tabel berikut ini:

Tabel 4. Perbandingan Ketuntasan Belajar Muatan IPA Kondisi Awal, Siklus I, dan Siklus II

\begin{tabular}{|c|c|c|c|c|c|c|c|c|}
\hline \multirow[t]{2}{*}{ No } & \multirow[t]{2}{*}{ KetuntasanBelajar } & \multirow[t]{2}{*}{ Nilai } & \multicolumn{2}{|c|}{ KondisiAwal } & \multicolumn{2}{|c|}{ Siklus I } & \multicolumn{2}{|c|}{ Siklus II } \\
\hline & & & Jumlah & $\%$ & Jumlah & $\%$ & Jumlah & $\%$ \\
\hline 1 & Tuntas & $\geq 75$ & 5 & $15 \%$ & 26 & $79 \%$ & 30 & $90 \%$ \\
\hline \multirow[t]{4}{*}{2} & BelumTuntas & $<75$ & 28 & $85 \%$ & 7 & $21 \%$ & 3 & $10 \%$ \\
\hline & Jumlah & & 33 & $100 \%$ & 33 & $100 \%$ & 33 & $100 \%$ \\
\hline & NilaiMaksimal & & \multicolumn{2}{|c|}{89} & \multicolumn{2}{|c|}{92} & \multicolumn{2}{|c|}{100} \\
\hline & Nilai Minimal & & \multicolumn{2}{|c|}{17} & \multicolumn{2}{|c|}{50} & \multicolumn{2}{|c|}{58} \\
\hline
\end{tabular}

Dari data di atas dapat dilihat bahwa hasil belajar muatan IPA siswa kelas 5 SDN Salatiga 10 mengalami peningkatan pada tiap siklusnya. Pada kondisi awal hanya terdapat 5 siswa atau $15 \%$ dari jumlah 33 siswa yang tuntas dengan nilai maksimal 89 dan nilai minimal 17. Setelah dilakukan tindakan siklus I mengalami peningkatan yaitu menjadi 26 siswa atau $79 \%$ dari jumlah keseluruhan 33 siswa yang tuntas dengan nilai maksimal 92 dan nilai minimal 50. Kemudian setelah dilakukan siklus II mengalami peningkatan kembali menjadi 30 siswa atau $90 \%$ dari jumlah keseluruhan 33 siswa dengan nilai maksimal 100 dan nilai minimal 58.

Pada tindakan siklus I terlihat siswa belum memunculkan sikap kerjasama saat berdiskusi, hal ini terlihat siswa dalam kelompok ada yang aktif mengerjakan adapula siswa yang kurang aktif. Hal lain siswa terlihat bingung dengan gambar yang diberikan guru sebagai alat untuk memudahkan siswa dalam memahamimateri. Dari kekurangan pada siklus I, maka perlu diadakan perbaikan pada tindakan siklus II, supaya siswa dapat bekerjasama dengan teman kelompok guru membimbing dan mengarahkan siswa dalam mengerjakan tugas kelompok. Agar siswa lebih mudah dalam memahami materi pelajaran guru mengganti gambar menjadi video agar lebih mudah dimengerti. Perbaikan tersebut dilakukan guna meningkatkan proses dan hasil belajar muatan IPA. Hasil penelitian yang 
dilakukan di kelas 5 SDN Salatiga 10 semester genap tahun ajaran 2017/2018 terjadi peningkatan pada proses dan hasil belajar pada muatan IPA pada pembelajaran siklus I dan siklus II dengan menerapkan model pembelajaran problem based learning. Hal ini dapat dilihat pada hasil observasi aktivitas guru dan siswa serta hasil belajar muatan IPA siswa pada kondisi awal hingga siklus II.

Hasil observasi aktivitas guru dan siswa mengalami peningkatan disetiap siklusnya. Hasil observasi aktivitas guru pada kondisi awal, memperoleh skor 49 dari jumlah skor keseluruhan 105 dengan persentase sebesar $46 \%$. Setelah dilakukannya tindakan siklus I terjadi peningkatan menjadi $76,47 \%$ dengan rata-rata skor 80,3 dari jumlah skor keseluruhan 105 , dan mengalami peningkatan kembali pada siklus II menjadi $88,57 \%$ dengan rata-rata skor 93 dari jumlah skor keseluruhan 105. Hasil observasi aktivitas siswa pada kondisi awal memperoleh skor 47 dari jumlah skor keseluruhan 120 dengan persentase sebesar 39\%. Setelah dilakukannya tindakan siklus I mengalami peningkatan pada menjadi 65,58\% dengan rata-rata skor 76 dari jumlah skor keseluruhan 120, dan pada siklus II mengalami peningkatan kembali menjadi 85.00\% dengan rata-rata skor 102 dari jumlah skor keseluruhan 120.

Hasil belajar muatan IPA siswa kelas 5 SDN Salatiga 10 juga mengalami peningkatan. Pada kondisi awal 28 siswa atau 85\% dari total keseluruhan siswa yang mendapatkan nilai kurang dari Kriteria Ketuntasan Minimal $(\mathrm{KKM} \geq 75)$ dan 5 siswa atau $15 \%$ dari total keseluruhan 33 siswa sudah mencapai Kriteria Ketuntasan Minimal (KKM). Nilai rata-rata pada kondisi awal 53, dengan nilai maksimal 89 dan nilai minimal 17. Setelah menerapkan model pembelajaran problem based learning pada siswa kelas 5 SDN Salatiga 10 pada siklus I meningkat, hal ini terbukti dari siswa yang telah mencapai nilai KKM (75) sebanyak 26 siswa sedangkan siswa yang belum mencapai KKM terdapat 7 siswa.Nilai rata-rata kelas juga meningkat pada siklus I yaitu 79,2 dengan nilai maksimal 92 sedangkan nilai minimal 50. Pada siklus II juga mengalami peningkatan hasil belajar muatan IPA, siswa yang telah mencapai nilai KKM (75) sebanyak 30 siswa sedangkan siswa yang belum mencapai nilai KKM terdapat 3 siswa. Nilai rata-rata kelas pada siklus II meningkat menjadi 85 dengan nilai tertinggi 100 sedangkan nilai terendah 58.

Perubahan pada proses dan hasil belajar muatan IPA siswa kelas 5 SDN Salatiga 10 terlihat yang semula dalam proses pembelajaran beracuan pada guru dan buku dapat menjadi lebih baik dan bermakna dengan adanya kegiatan diskusi, menyelesaikan tugas dengan belajar mengamati secara langsung dengan arahan dan bimbingan dari guru.Dari pembahasan di atas dapat disimpulkan bahwa tindakan yang dilakukan disetiap siklus mengalami peningkatan dikarenakan pada proses pembelajaran siswa terlibat secara langsung dalam belajar, melakukan diskusi, siswa dihadapkan pada masalah dan menemukan sendiri solusi untuk memecahkan masalah tersebut. Dari hasil penelitian yang telah diuraikan di atas dapat membuktikan bahwa dengan menerapkan model pembelajaran problem based learning dapat meningkatkan proses dan hasil belajar pada muatan IPA siswa kelas 5 SDN Salatiga 10. Hasil tersebut selaras dengan penelitianyang dilakukan Rini dan Mawardi, bahwa pembelajaran menggunakan model problem based learning dapat meningkatkan keterampilan proses saintifik pada kategori tinggi $(71,6 \%)$ pada rata-rata siklus I dan pada siklus II berada pada kategori sangat tinggi (83\%), serta meningkatkan hasil belajar IPA pada siklus I meningkat menjadi 77 dan ketuntasan belajarnya $70 \%$ pada kategori tinggi, serta meningkat lagi pada siklus II sebesar 86 dengan ketuntasan belajar $87 \%$ pada kategori sangat tinggi. , Mustamilah (2015).

Keunggulan atau kelebihan penelitian ini dari penelitian lain yaitu penelitian ini dilakukan untuk mengukur proses aktivitas guru maupun siswa dan hasil belajar muatan IPA. Pengukuran aktivitas guru dan siswa menggunakan rubrik penilaian, apakah guru dan siswa melakukan kegiatan yang sesuai dengan indikator aktivitas guru dan siswa yang telah peneliti tentukan. Dari observasi aktivitas siswa, apakah siswa melaksanakan tugas sesuai dengan materi yang diberikan guru, menanggapi tugas dari temannya, siswa dapat 
mempresentasikan tugasnya di depan kelas dan dari hasil belajar dapat diukur dengan mengerjakan soal evaluasi.

\section{Simpulan dan Saran}

Berdasarkan hasil penelitian dan pembahasan yang telah disampaikan, maka dapat disimpulkan bahwa penelitian ini dapat meningkatkan proses dan hasil belajar muatan IPA siswa kelas 5 SDN Salatiga 10. Hal ini dapat dilihat terjadi peningkatan proses aktivitas guru maupun siswa dan hasil belajar. Pada kondisi awalhasil observasi aktivitas guru memperoleh skor 49 dengan persentase sebesar $46 \%$. Setelah dilakukannya tindakan siklus I meningkat menjadi $76,47 \%$ dengan rata-rata skor 80,3 , dan mengalami peningkatan kembali pada siklus II menjadi $88,57 \%$ dengan rata-rata skor 93 . Hasil observasi aktivitas siswa pada kondisi awal memperoleh skor 47 dengan persentase sebesar 39\%. Setelah dilakukannya tindakan siklus I mengalami peningkatan menjadi $65,58 \%$ dengan rata-rata skor 76 , dan pada siklus II mengalami peningkatan kembali menjadi $85.00 \%$ dengan rata-rata skor 102.Sedangkan untuk hasil belajar muatan IPA siswa kelas 5 SDN Salatiga 10 juga mengalami peningkatan. Pada kondisi awal menunjukkan ketuntasan belajar sebanyak 5 siswa (15\%) meningkat pada siklus I sebanyak 26 siswa (79\%) dan pada siklus II mengalami peningkatan menjadi 30 siswa (90\%).

Berdasarkan kesimpulan yang telah disampaikan, peneliti memberikan beberapa saran supaya dapat dipahami: (1) guru dapat menjadikan sebagai referensi penerapan model pembelajaran problem based learning dalam proses pembelajaran muatan IPA, (2) guru harus memberikan pengalaman langsung kepada siswa agar kegiatan pembelajaran yang berlangsung dapat bermakna, (3) guru harus dapat memberikan suasana yang menyenangkan dan menarik saat proses pembelajaran.

\section{Daftar Rujukan}

Daryanto. (2014). Pembelajaran Tematik, Terpadu, Terintegrasi (Kurikulum 2013). Yogyakarta: Gava Media.

Hamalik, Oemar. 2013. Proses Belajar Mengajar. Jakarta: Bumi Aksara

Hosnan, M. 2014. Pendekatan Saintifik dan Kontekstual. Jakarta: Ghalia Indonesia: DIVA Press.

Huda, Miftahul. (2013). Model-model Pengajaran dan Pembelajaran. Yogyakarta: Pustaka Pelajar.

Kemendikbud. (2014). Materi Pelatihan Guru Implementasi Kurikulum 2013 Tahun 2014. Jakarta: BPSDMPK - PMP - Kemendikbud

Kristin, F. 2016. Efektivitas Model Pembelajaran Kooperatif Tipe STAD Ditinjau Dari Hasil Belajar IPS Siswa Kelas 4 SD. Scholaria: Jurnal Pendidikan dan Kebudayaan, 6(2).

Mulyasa. (2014). Guru dalam Implementasi Kurikulum 2013. Bandung: Remaja Rosdakarya.

Pujiono, Setyawan. 2008. Desain Penelitian Tindakan Kelas dan Teknik Pengembangan Kajian Pustaka. Yogyakarta: Universitas Negeri Yogyakarta

Rini, R., \& Mawardi. (t.thn.). Peningkatan Keterampilan Proses Saintifik Dan Hasil Belajar Siswa Kelas 4 SDN Slungkep 02 Tema Peduli Terhadap Makhluk Hidup Menggunakan Model Problem Based Learning. Jurnal, 103. 
Rusman. 2012. Model-model Pembelajaran Mengembangkan Profesionalisme Guru. Jakarta: Raja Grafindo Persada.

Sudjana, Nana. 2010. Penilaian Hasil Proses Belajar Mengajar. Bandung: PT. Remaja Rosdakarya.

Suyatno. (2009). Menjelajah Pembelajaran Inovatif. Surabaya: Masmedia Buana

Pustaka.Trianto. 2010. Model Pembelajaran Terpadu. Jakarta: PT Bumi Aksara

Warsono, Hariyanto. 2013. Pembelajaran Aktif. Bandung: PT. Remaja Rosdaskarya.

Widhiatma, Y. (2017). Penerapan Model Problem Based Learning Untuk Meningkatkan Hasil Belajar IPA Siswa Kelas 4. e-jurnalmitrapendidikan, 451-453. 